\title{
Potential of aquacultural sludge treatment for aquaponics: evaluation of nutrient mobilization under aerobic and anaerobic conditions
}

\author{
Hendrik Monsees ${ }^{1,2, *}$, Jonas Keitel ${ }^{1,3}$, Maurice Paul ${ }^{1,2}$, Werner Kloas ${ }^{1,2}$, Sven Wuertz ${ }^{1,2}$ \\ ${ }^{1}$ Leibniz-Institute of Freshwater Biology and Inland Fisheries, Müggelseedamm 310, 12587 Berlin, Germany \\ ${ }^{2}$ Albrecht Daniel Thaer-Institute of Agricultural and Horticultural Sciences, Humboldt University Berlin, \\ Unter den Linden 6, 10099 Berlin, Germany \\ ${ }^{3}$ Technical University of Berlin, Straße des 17. Juni 135, 10623 Berlin, Germany
}

\begin{abstract}
In recirculating aquaculture systems (RAS), mechanical removal of suspended solids by clarifiers or drum filters provides an organic mixture rich in nutrients. Still, in most traditional RAS, this sludge is discharged directly or following dewatering. Here, the potential recycling of nutrients from sludge is assessed, comparing aerobic and anaerobic mobilization of nutrients experimentally, ultimately aiming at an application in aquaponic systems. Nutrient mobilization processes were studied, monitoring soluble nutrients photometrically in the treatment tanks $\left(\mathrm{NO}_{3}{ }^{-}-\mathrm{N}, \mathrm{NO}_{2}^{-}-\mathrm{N}\right.$, total ammonia nitrogen, soluble reactive phosphorus [SRP], $\mathrm{K}^{+}, \mathrm{Mg}^{2+}$ and $\left.\mathrm{Fe}^{2+}\right)$, the nutrient composition of the sludge (total phosphorus, Fe, Mn, $\mathrm{Al}, \mathrm{S}, \mathrm{Mg}, \mathrm{Ca}$ ) by inductively coupled plasma optical emission spectrometry, as well as C:N ratio, total solids (TS) and total suspended solids (TSS). Aerobic treatment (aerated, AT) resulted in a 3.2 -fold increase in mean $( \pm$ SD) SRP from $9.4( \pm 0.7)$ to $29.7( \pm 2.1) \mathrm{mg} \mathrm{l}^{-1}$, most likely owing to a decrease in $\mathrm{pH}$. In contrast, in the anaerobic treatment (unaerated, UT), SRP remained unchanged between $9.4( \pm 0.7)$ and $9.3( \pm 0.4)$ $\mathrm{mg} \mathrm{l}^{-1}$. Both treatments resulted in increased $\mathrm{K}^{+}$concentrations from $28.1( \pm 1.5)$ to $36.8( \pm 2.3) \mathrm{mg}$ $\mathrm{l}^{-1}$ in AT and to $32.2( \pm 2.3) \mathrm{mg} \mathrm{l}^{-1}$ in UT. AT revealed best mobilization of $\mathrm{P}$ and $\mathrm{K}^{+}$without major losses of $\mathrm{NO}_{3}{ }^{-}-\mathrm{N}$. Thus, aerobic treatment of water-sludge mixture has a high potential for significant improvements of nutrient recycling in aquaponics.
\end{abstract}

KEY WORDS: Aquaponics $\cdot$ Phosphate recovery $\cdot$ Nitrate $\cdot$ Sludge $\cdot$ Aerobic $\cdot$ Anaerobic $\cdot$ Nutrient recycling

\section{INTRODUCTION}

Public perception of aquaculture is often critical, raising concerns about eutrophication and pollution of the aquatic environment due to direct emissions of nutrients from fish farms (Edwards 2015, Zhang et al. 2015). Often ignored, solid waste originating from faeces and uneaten feed pellets represent a substantial nutrient reservoir. Upon microbial conversion, chemical mobilization and leaching, nutrient emissions may induce algal blooms, oxygen depletion and mass mortalities among aquatic or-

*Corresponding author: h.monsees@igb-berlin.de

$\S_{\text {Corrections were made after publication. For details see }}$ www.int-res.com/abstracts/aei/v9/c_p9-18

This corrected version: March 29, 2017 ganisms (Zhang et al. 2015). Over the last 2 decades, recirculating aquaculture systems (RAS) have been rapidly evolving to reduce such impacts on the environment. Undoubtedly, RAS technology has a great potential, particularly assigned to the efficient use of water and space (Gutierrez-Wing \& Malone 2006) and supports a sustainable development of the fast growing aquaculture industry. Environmental legislation and, from an economic perspective, fees for waste disposal and nutrient emissions represent main motivations to improve waste management and reduce nutrient emission supporting the

(C) The authors 2017. Open Access under Creative Commons by Attribution Licence. Use, distribution and reproduction are unrestricted. Authors and original publication must be credited.

Publisher: Inter-Research · www.int-res.com 
development of sound environmentally friendly aquaculture production.

RAS usually comprise 2 main water treatment steps. First, mechanical filters such as clarifiers or drum filters are used to concentrate suspended solids, discharged either after dewatering or directly with the backwash. Subsequently in a biofilter, toxic ammonia, $\left(\mathrm{NH}_{4}{ }^{+} / \mathrm{NH}_{3}\right)$ excreted from the fish gills, is converted to nitrate $\left(\mathrm{NO}_{3}{ }^{-}\right)$by nitrifying bacteria (Paredes et al. 2007). Despite the large variability observed between species, $60-90 \%$ of the excreted nitrogen is dissolved (van Rijn 2013). In contrast to classical RAS, aquaponic systems make use of such soluble nutrients derived from the fish unit to grow plants in an integrated hydroponic unit (Goddek et al. 2015). Here, standing stock of the RAS sustains the growth of the crop plants hence determining the dimensions of the hydroponic production (Rakocy et al. 2006). Consequently, in a well-balanced system, additional nitrogen fertilization is not required.

In contrast, phosphorus (P) in the process water is generally limited, but is essential for plant growth (Dawson \& Hilton 2011) and can only be assimilated by plants as dissolved inorganic phosphate $\left(\mathrm{PO}_{4}{ }^{3-}\right.$; hereafter soluble reactive phosphorus, SRP). A high percentage of the dietary $\mathrm{P}$ is not retained in fish but excreted and dissolved P strongly adsorbs onto particles (Neori et al. 2007). Consequently, feed leftovers and fish faeces are the main sources for $\mathrm{P}$, either in organic form or inorganic as $\mathrm{PO}_{4}{ }^{3-}$ (Barak \& van Rijn 2000). Thus, mechanical removal of suspended solids removes a major part of $\mathrm{P}$ without considering further strategies for recycling. Recent fishmeal substitution in modern diets reduces SRP (Hua \& Bureau 2006) but further increases the deposition of plant-derived organic phosphorus in the sludge.

In addition to $\mathrm{P}$, the supply of potassium $\left(\mathrm{K}^{+}\right)$is often suboptimal in aquaponic systems (Rakocy et al. 2006). Consequently, it has become standard practice in aquaponics to use synthetic chemical fertilizers, mainly nitrogen, phosphate and potassium (NPK-fertilizer) to formulate aquaponic media if specific nutrient profiles are not met (Rennert et al. 2011).

To date, the management of aquacultural sludge mostly aimed for improved water recycling in RAS as well as in aquaponics. Obviously, optimization strategies in RAS and aquaponics are quite opposite. In RAS, efforts focus on higher nutrient retention in the fish or the use of sludge as a nutrient sink. In aquaponics, retention of nutrients in the fish is not necessarily prioritized. Instead, optimized mobiliza- tion of nutrients is a key factor to ensure sustainability of the system. Currently, the prevailing approach used in RAS is anaerobic sludge digestion to reduce organic matter (Mirzoyan et al. 2010, Jung \& Lovitt 2011). Here, to mobilize $\mathrm{P}$, manipulation of $\mathrm{pH}$ is often carried out, either by addition of acids or indirectly via microbial fermentation (Jung \& Lovitt 2011). Only very few studies considered aerobic treatment for nutrient recycling of sludge where inorganic $\mathrm{P}$ is mobilised from organic $\mathrm{P}$ compounds by microbial dephosphorylation (Rakocy et al. 2007, Neori et al. 2007). Still, high mobilization rates of nutrients under aerobic conditions have been documented (Neori et al. 2007, Rakocy et al. 2007). Furthermore, under aerobic conditions, excessive nitrogen loss due to denitrification is prevented. Here, relevance of nitrogen recycling remains to be evaluated in a comparative approach under realistic production conditions, as a major part of nitrogen is actually soluble. More importantly, realistic data of $\mathrm{P}$ and $\mathrm{K}$ mobilization is needed to improve nutrient management in aquaponics.

In this study, we investigated the potential utilization of aquaculture sludge (i.e. solid waste collected in the mechanical treatment unit such as clarifier or drum filter) comparatively assessing nutrient mobilization under aerobic and anaerobic conditions. This study was integrated in a 6 mo trial on the optimization of a coupled and a decoupled aquaponic system (H. Monsees et al. unpubl.).

Optimizing sludge management should ultimately provide sound data to (1) improve environmental sustainability in the context of nutrient recycling and reduced emissions as well as profitability (reduced costs due to high water recovery from the sludge, decreased fertilization and, most importantly, lower waste and emission fees) and (2) increase the selfreliance of aquaponics. Finally, this will support the development of an automated or semi-automated reactor which will allow continuous, optimized nutrient mobilization to support a closed nutrient loop in aquaponics irrespective of the mechanical filter used (e.g. drum filter, clarifier).

\section{MATERIALS AND METHODS}

\section{Aquaponic system}

Experiments were conducted at the aquaponic research facility of the Leibniz-Institute of Freshwater Ecology and Inland Fisheries (IGB, Berlin, Germany), using a RAS with a total water volume of 


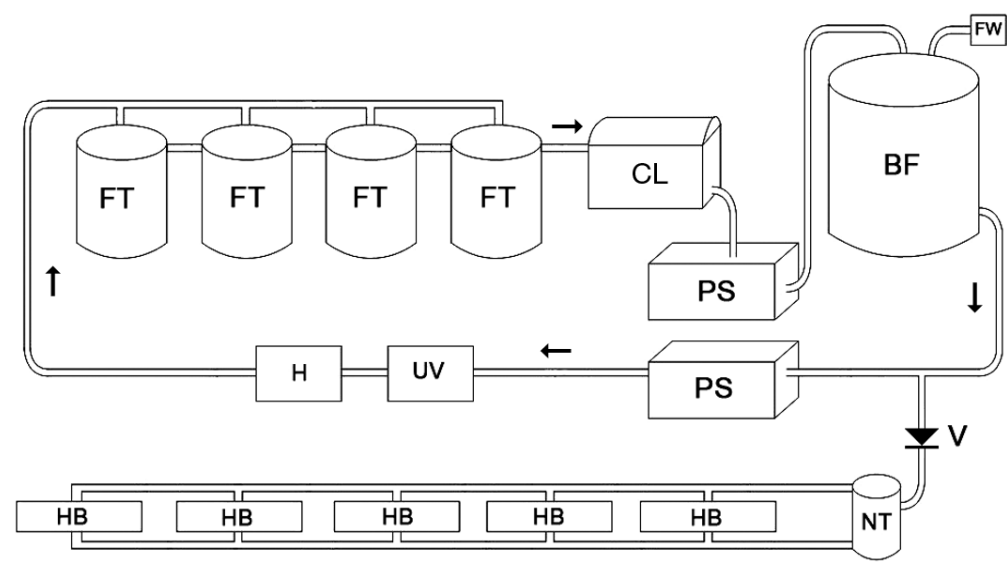

Fig. 1. Coupled aquaponic system, comprising a recirculating aquaculture system and a hydroponic unit. FT: fish tank(tanks are set up in parallel, with each outflow draining to the clarifier via an open channel behind the tanks); CL: clarifier; PS: pump sump; BF: biofilter; FW: fresh water supply; UV: UV disinfection unit (optional); H: heater (optional); HB: hydroponic beds (nutrient flow technique); NT: nutrient media reservoir; V: 1-way valve method \#8155; $\mathrm{K}^{+}$, tetraphenylborate method \#8049; $\mathrm{Mg}^{2+}$, calmagite colorimetric method \#8030; $\mathrm{Fe}^{2+}, 1$ 1,10-phenanthroline method \#8146; all methods from the manufacturer's manual; Hach Lange) in the water were determined spectrophotometrically (DR3900, Hach Lange) at the inlet of a fish tank and the outlet of the clarifier (see Table 4). SRP (see Figs. 2a \& 3a) was measured photometrically (Spekol®) 1500, Analytik Jena) at a wavelength of $880 \mathrm{~nm}$ according to the molybdenum blue method (Murphy \& Riley 1962). Conditions in the RAS are summarized in Table 1. The water-sludge mixture $\left(1.5 \mathrm{~m}^{3}\right)$ from the clarifier was collected once weekly in a $2 \mathrm{~m}^{3}$ tank, homogenized with a pump and used for the subsequent experiments.
$16.5 \mathrm{~m}^{3}$ (Fig. 1). Three separate rearing tanks $\left(1.7 \mathrm{~m}^{3}\right.$ each) were stocked with a total of $316 \mathrm{~kg}$ tilapia Oreochromis niloticus L. at rearing densities of $62 \mathrm{~kg}$ $\mathrm{m}^{-3}$ per tank.

Fish originated from a brood stock established at the IGB and were not further characterized. Removal of suspended matter was carried out with a clarifier $\left(1.5 \mathrm{~m}^{3}\right)$. Over the experimental period, fish were fed a commercial diet at $0.8 \%$ of their body weight per day (Aller Float 37/10 2 mm, Emsland-Aller Aqua: $37 \%$ protein, $10 \%$ fat, $38.5 \%$ nitrogen-free extract, $6 \%$ ash, $3 \%$ fibre, $1.2 \% \mathrm{P}$ of dry weight; estimated environmental impact (feed conversion ratio $=1.0$ ): $4.7 \mathrm{~g} \mathrm{~N}$ and $3 \mathrm{~g} \mathrm{P}$ in faeces per $\mathrm{kg}$ feed, $27 \mathrm{~g} \mathrm{~N}$ and $2.7 \mathrm{~g} \mathrm{P}$ in water per $\mathrm{kg}$ feed).

Temperature, $\mathrm{pH}$ and oxygen were determined daily (HQ40d multi, Hach Lange); pH was regulated with $\mathrm{Ca}(\mathrm{OH})_{2}$ to maintain a target $\mathrm{pH}$ of $7( \pm 1)$ (Table 1$)$. Selected nutrients $\left(\mathrm{NO}_{3}{ }^{-}-\mathrm{N}\right.$, cadmium reduction method \#8039; $\mathrm{NO}_{2}^{-}-\mathrm{N}$, USEPA diazotization method \#8507; total ammonia nitrogen [TAN], salicylate

Table 1. Rearing conditions for tilapia during the experimental period

\begin{tabular}{|lc|}
\hline Parameter & Target value \\
\hline Temperature $\left({ }^{\circ} \mathrm{C}\right)$ & $26 \pm 1$ \\
Oxygen $\left(\mathrm{mg} \mathrm{l}^{-1}\right)$ & $>5$ \\
pH & $7 \pm 1$ \\
Stocking density $\left(\mathrm{kg} \mathrm{m}^{-3}\right)$ & $62 \pm 2.5$ \\
Feeding rate $(\%)$ & 0.8 \\
Feed $\left(\mathrm{kg} \mathrm{d}^{-1}\right)$ & 2.5 \\
\hline
\end{tabular}

\section{Determination of total suspended solids (TSS) in the RAS}

For TSS, water samples $(620 \mathrm{ml})$ were taken in triplicate at the inflow of a fish tank prior to feeding at 09:00 h (0 h), and 3, 6, 9 and $24 \mathrm{~h}$ thereafter. Briefly, samples were filtered through pre-weighed $0.45 \mu \mathrm{m}$ CA membrane filters (GE Healthcare), freeze-dried to constant weight and weighed.

\section{Sludge composition}

Total solids (TS) were determined in a subsample of the homogenized water-sludge mix after centrifugation and freeze-drying to constant weight. Total phosphorus (TP), iron (Fe), manganese (Mn), aluminum $(\mathrm{Al})$, sulfur $(\mathrm{S})$, magnesium $(\mathrm{Mg})$ and calcium $(\mathrm{Ca})$ were determined by inductively coupled plasma optical emission spectrometry (iCAB 6000, Thermo Fisher Scientific) after wet digestion ( $\mathrm{HCl} 37 \%, \mathrm{HNO}_{3} 65 \%$, volumetric ratio 1:3) in a high pressure microwave oven (Gigatherm). C:N analysis was performed using freeze-dried, weighed sediment packed in tin foil and analyzed in a Vario EL@ system (Elementar Analysensysteme). Dry weight: wet weight ratio was determined in freeze-dried aliquots of fresh sludge $(n=15)$.

\section{Expt 1: Anaerobic lab-scale nutrient mobilization}

For the verification of nutrient mobilization under anaerobic conditions in a closed container, lab-scale 
experiments were performed. The water-sludge mix was transferred to 18 centrifugation tubes $(55 \mathrm{ml})$, ensuring that no air remained inside the tubes. To minimize temperature variation, tubes were incubated on a rotation shaker (Heidolph Reax) in a climate chamber at $25 \pm 0.5^{\circ} \mathrm{C}$ for $4 \mathrm{~d}$ (with an additional $4 \mathrm{~d}$ for SRP sampling only). Each day, 3 tubes were sampled for nutrient determination (SRP, $\mathrm{NO}_{3}{ }^{-}-\mathrm{N}, \mathrm{NO}_{2}{ }^{-}-\mathrm{N}, \mathrm{TAN}, \mathrm{K}^{+}, \mathrm{Mg}^{2+}$ and $\mathrm{Fe}^{2+}$ ). Briefly, samples were centrifuged (Multifuge 1-sr, Thermo Fisher) for $10 \mathrm{~min}$ at $1900 \times \mathrm{g}$. Directly before analysis, the liquid phase was filtered through a $0.45 \mu \mathrm{m}$ nylon syringe filter (Braun). According to O'Sullivan \& Reynolds (2004), dissolved $\mathrm{O}_{2}<0.1 \mathrm{mg} \mathrm{l}^{-1}$ is considered anaerobic here. To exclude oxygenation of the small volume during measurement, oxygen was determined separately, using $500 \mathrm{ml}$ glass bottles ( $\mathrm{n}=3$ ) filled completely with water-sludge mix and continuously monitored with an oxygen probe inserted through a parafilm seal. Additionally bottles were covered with aluminium foil to prevent algal growth and placed on a magnetic stirrer (Heidolph MR 1000) for continuous movement of the liquid. Oxygen concentration was measured at $5 \mathrm{~min}$ intervals.

\section{Expt 2: Aerated (aerobic) and unaerated (anaerobic) nutrient mobilization}

Homogenized water-sludge mix was distributed to six 301 polyethylene tanks providing an aerated (compressed air via airstones), aerobic (AT) and an unaerated, anaerobic treatment (UT), assessed in 3 replicates each over $14 \mathrm{~d}$ and repeated 3 times. All boxes were covered with a tight lid to prevent evaporation and incubated in a water bath $(1.5 \times 1.5 \mathrm{~m}$ glass fibre tank equipped with two $300 \mathrm{~W}$ heaters and a pump for constant circulation) at $26^{\circ} \mathrm{C} \pm 0.6^{\circ} \mathrm{C}$ for the $14 \mathrm{~d}$. The water bath was additionally insulated with foil and covered with thick, black pond foil to prevent algal growth. Samples for water analysis were collected in $50 \mathrm{ml}$ centrifugation tubes and directly analyzed for dissolved ions as described for Expt 1.

\section{Statistical analysis}

Data are presented as means \pm standard deviation (SD) of $\mathrm{n}$ samples. Statistical analysis was performed using Graphpad Prism (GraphPad Software). Data were tested for normality (Shapiro-Wilk) and equal variance (Kruskal-Wallis). Multiple comparison was carried out by non-parametric Dunn's test $(p<0.05)$, and pairwise comparisons were carried out by nonparametric Mann-Whitney $U$ test $(\mathrm{p}<0.05)$.

\section{RESULTS}

\section{Characterization of the sludge-water mixture}

Sludge collected successively from a full production cycle for tilapia under realistic conditions was comparable between all 4 replicates with regard to element composition (Table 2). Only slight variations $(<20 \%)$ were observed, particularly $\mathrm{P}, \mathrm{Ca}$, and most prominently in TS. A mean $\mathrm{P}$ deposition of $59.4 \mathrm{~g} \mathrm{wk}^{-1}$ was observed in the clarifier. TSS was highest in the morning (Table 3), but decreased within $3 \mathrm{~h}$, fluctuating around $1.5 \mathrm{mg} \mathrm{l}^{-1}$ $( \pm 0.2)$.

The soluble nutrients measured at the outlet of the clarifier and at the inlet of the fish tanks were comparable (Table 4). As expected, TAN and $\mathrm{NO}_{2}{ }^{-}-\mathrm{N}$ in the rearing water of the RAS were always below critical threshold. $\mathrm{NO}_{3}{ }^{-}-\mathrm{N}$ concentration varied, providing different starting points for the experiments (highest concentration during the first sampling of Expt 2). Phosphate, magnesium and potassium also varied slightly, but not strictly correlated to each other.

Table 2. Elemental analysis by inductively coupled plasma optical emission spectrometry, C:N ratio and total solids (TS) of freeze-dried sludge collected from the clarifier $\left(1.5 \mathrm{~m}^{3}\right)$ of a recirculating aquaculture system producing tilapia under realistic conditions in 4 technical replicates, illustrating the respective variation in sludge harvested during the experimental period

\begin{tabular}{|lccccccccccc|}
\hline Replicate & $\begin{array}{c}\mathrm{P} \\
\left(\mathrm{mg} \mathrm{g}^{-1}\right)\end{array}$ & $\begin{array}{c}\mathrm{Mg} \\
\left(\mathrm{mg} \mathrm{g}^{-1}\right)\end{array}$ & $\begin{array}{c}\mathrm{Ca} \\
\left(\mathrm{mg} \mathrm{g}^{-1}\right)\end{array}$ & $\begin{array}{c}\mathrm{Fe} \\
\left(\mathrm{mg} \mathrm{g}^{-1}\right)\end{array}$ & $\begin{array}{c}\mathrm{Mn} \\
\left(\mathrm{mg} \mathrm{g}^{-1}\right)\end{array}$ & $\begin{array}{c}\mathrm{Al} \\
\left(\mathrm{mg} \mathrm{g}^{-1}\right)\end{array}$ & $\begin{array}{c}\mathrm{S} \\
\left(\mathrm{mg} \mathrm{g}^{-1}\right)\end{array}$ & $\begin{array}{c}\mathrm{C} \\
(\%)\end{array}$ & $\begin{array}{c}\mathrm{N} \\
(\%)\end{array}$ & $\begin{array}{c}\mathrm{C}: \mathrm{N} \\
\left(\mathrm{g} \mathrm{l}^{-1}\right)\end{array}$ \\
\hline 1 & 31.27 & 3.32 & 56.35 & 3.69 & 0.27 & 3.31 & 6.75 & 35.59 & 3.87 & 9.18 & $1.23 \pm 0.05$ \\
2 & 25.46 & 3.30 & 47.77 & 2.84 & 0.23 & 2.22 & 6.04 & 37.61 & 4.08 & 9.21 & $1.14 \pm 0.04$ \\
3 & 28.84 & 3.25 & 50.51 & 2.95 & 0.21 & 2.69 & 5.86 & 36.54 & 4.00 & 9.15 & $1.65 \pm 0.03$ \\
4 & 35.92 & 3.22 & 70.01 & 3.38 & 0.27 & 3.18 & 7.53 & 33.95 & 4.43 & 7.67 & - \\
\hline
\end{tabular}


Table 3. Total suspended solids (TSS, g dry weight $1^{-1}$ rearing water) in a tilapia recirculating aquaculture system over $24 \mathrm{~h}$. Samples were taken at the inlet of a fish tank; sampling started at 09:00 $\mathrm{h}$ before feeding. Data are means $\pm \mathrm{SD}(\mathrm{n}=3)$

\begin{tabular}{|lc|}
\hline Time $(\mathrm{h})$ & TSS $\left(\mathrm{mg} \mathrm{l}^{-1}\right)$ \\
\hline 0 & $2.3 \pm 0.1$ \\
3 & $1.5 \pm 0.1$ \\
6 & $1.6 \pm 0.3$ \\
9 & $1.4 \pm 0.3$ \\
24 & $2.2 \pm 0.2$ \\
\hline
\end{tabular}

\section{Expt 1: Anaerobic lab-scale mobilization}

Within $8 \mathrm{~d}$, SRP increased steadily in all 3 successively assessed sludge-water mixtures. At $0 \mathrm{~d}$, SRP ranged between 7.8 and $9.2 \mathrm{mg} \mathrm{l}^{-1}$ and increased significantly ( $\mathrm{p}<0.05$, Dunn's) to $11.2-12.6 \mathrm{mg} \mathrm{l}^{-1}$ (Fig. 2a). Only minor oscillations were observed in $\mathrm{K}^{+}$, revealing concentrations of approximately $25.0 \mathrm{mg} \mathrm{l}^{-1}$ (Fig. 2b). The $\mathrm{NO}_{3}{ }^{-} \mathrm{N}$ concentration was reduced by $97 \%$ within $4 \mathrm{~d}$ from $58( \pm 8)$ to $1.5( \pm 0.2) \mathrm{mg} \mathrm{l}^{-1}$ (Fig. 2c). In parallel, TAN increased substantially $(\mathrm{p}<0.05$, Dunn's) from $<1 \mathrm{mg} \mathrm{l}^{-1}$ to $>10 \mathrm{mg} \mathrm{l}^{-1}$ (Fig. 2d). $\mathrm{NO}_{2}^{-}-\mathrm{N}$ concentrations decreased significantly $(\mathrm{p}<0.05$, Dunn's) from $1.4( \pm 0.4)$ to $0.03( \pm 0.03) \mathrm{mg} \mathrm{l}^{-1}$ (Fig. 2e). $\mathrm{Mg}^{2+}$ did not vary over the $4 \mathrm{~d}\left(64.1 \pm 1.2 \mathrm{mg} \mathrm{l}^{-1}\right.$; Fig. 2f). $\mathrm{Fe}^{2+}$ concentrations were always below the detection limit ( $<0.01 \mathrm{mg} \mathrm{l}^{-1}$; data not shown). Measurement of oxygen concentration in sealed glass bottles (see 'Materials and methods') revealed a complete depletion of oxygen from 5.28 to $0 \mathrm{mg} \mathrm{l}^{-1}$ within $45 \mathrm{~min}$ (data not shown), confirming anaerobic conditions.

\section{Expt 2: Aerobic and anaerobic mobilization}

Within 14 d (Day 0 to Day 13), SRP increased significantly ( $\mathrm{p}<0.05$, Mann-Whitney) in the AT from 9.4

Table 4. Soluble nutrients $\left(\mathrm{PO}_{4}{ }^{3-}, \mathrm{K}^{+}\right.$, total ammonia nitrogen [TAN], $\mathrm{NO}_{3}{ }^{-}-\mathrm{N}$, $\mathrm{NO}_{2}{ }^{-}-\mathrm{N}, \mathrm{Mg}^{2+}$ ) measured at the inlet of a fish tank and the outlet of the clarifier of a tilapia recirculating aquaculture system. Data are the results of 3 successive samplings. nd: parameters not determined

\begin{tabular}{|lcccccc|}
\hline $\begin{array}{l}\text { Parameter } \\
\left(\mathrm{mg} \mathrm{l}^{-1}\right)\end{array}$ & $\begin{array}{c}\text { Sampling 1 } \\
\text { Tank }\end{array}$ & \multicolumn{2}{c}{$\begin{array}{c}\text { Sampling 2 } \\
\text { Clarifier }\end{array}$} & Tank & Clarifier & \multicolumn{2}{c|}{$\begin{array}{c}\text { Sampling 3 } \\
\text { Tank }\end{array}$} & Clarifier \\
\hline $\mathrm{TAN}$ & 0.3 & 0.2 & 0.2 & 0.4 & 0.2 & 0.4 \\
$\mathrm{NO}_{2}{ }^{-}-\mathrm{N}$ & 0.1 & 0.2 & 0.1 & 0.1 & nd & nd \\
$\mathrm{NO}_{3}{ }^{-}-\mathrm{N}$ & 64.0 & 63.0 & 48.5 & 50.0 & 46.5 & 52.5 \\
$\mathrm{PO}_{4}{ }^{3-}$ & 7.9 & 8.0 & 8.1 & 7.9 & 9.7 & 9.5 \\
$\mathrm{Mg}^{2+}$ & 61.6 & 63.0 & 59.2 & 62.6 & 70.0 & 70.4 \\
$\mathrm{~K}^{+}$ & 27.0 & 26.5 & 24.5 & 24.5 & 28.5 & 27.0 \\
\hline
\end{tabular}

$( \pm 0.8)$ to $29.7( \pm 2.1) \mathrm{mg} \mathrm{l}^{-1} \mathrm{PO}_{4}{ }^{3-}$ (Fig. 3a). In contrast, no changes were observed in the UT. In the AT, $\mathrm{K}^{+}$concentration increased by $30 \%$ from from 28.1 ( \pm 1.5) to $36.8( \pm 2.3) \mathrm{mg} \mathrm{l}^{-1}$ between $0 \mathrm{~d}$ and $14 \mathrm{~d}$ (Fig. 3b). Again, $\mathrm{NO}_{3}{ }^{-}-\mathrm{N}$ dropped from $68.2( \pm 2.8)$ to $9.4( \pm 4.4) \mathrm{mg} \mathrm{l}^{-1}$ in the UT and was thus reduced by $86 \%$ within 14 d (Fig. 3c); in contrast, only a minor reduction of $16 \%$ from $68.2( \pm 2.8)$ to $55.1( \pm 11.3) \mathrm{mg}$ $\mathrm{I}^{-1}$ was observed in the AT (Fig. 3c). In the UT, TAN increased from $1.0( \pm 0.1)$ to $7.9( \pm 0.8) \mathrm{mg} \mathrm{l}^{-1}$, but decreased from $1.0( \pm 0.1)$ to $0.1( \pm 0.1) \mathrm{mg} \mathrm{l}^{-1}$ in the AT (Fig. 3d). Initially, $\mathrm{NO}_{2}^{-}-\mathrm{N}$ decreased in both treatments, but from Day 7 in the UT it then increased to $0.2( \pm 0.1) \mathrm{mg} \mathrm{l}^{-1}$ (Fig. 3e). In the AT, $\mathrm{NO}_{2}{ }^{-}-\mathrm{N}$ dropped continuously from $1.3( \pm 0.4)$ to 0.01 $( \pm 0.005) \mathrm{mg} \mathrm{l}^{-1}$. No changes in $\mathrm{Mg}^{2+}$ were observed over time, neither between treatments nor within a treatment (AT: 61-73 $\mathrm{mg} \mathrm{l}^{-1}$; UT: 53-74 $\mathrm{mg} \mathrm{l}^{-1}$; Fig. 3f). In both treatments, iron concentrations were always below the detection limit $\left(\mathrm{Fe}^{2+} \leq 0.01 \mathrm{mg} \mathrm{l}^{-1}\right.$; data not shown).

AT and UT revealed opposite progression in $\mathrm{pH}$, increasing from $6.2( \pm 0.02)$ to $7.0( \pm 0.2)$ in the UT and decreasing to $5.3( \pm 0.01)$ in the AT (Fig. 4).

\section{DISCUSSION}

Here, sludge obtained from the clarifier of a RAS was used to demonstrate the potential of optimized nutrient mobilization for aquaponics, aiming at an easy-to-handle, inexpensive/economical incubator. Aeration treatment (AT) increased the P concentration by $330 \%$ and the $\mathrm{K}^{+}$concentration by $31 \%$ within $14 \mathrm{~d}$ of incubation. This is highly relevant since most $\mathrm{K}^{+}$and $\mathrm{P}$ input via the feed is actually retained in the sludge. Current practice does not make use of this resource; instead, $\mathrm{P}$ and $\mathrm{K}$ concentrations in the process water are limited, requiring supplementation for aquaponics (NPKfertilizer) (Rennert et al. 2011). Additionally, the AT reduced $\mathrm{NO}_{3}{ }^{-}-\mathrm{N}$ concentrations by just $16 \%$ compared to $97 \%$ in the unaerated treatment (UT), most probably due to denitrification. Thus, AT is a good compromise considering the overall supply of the nutrients for aquaponic applications.

Following AT, the phosphate concentration of $27.7 \mathrm{mg} \mathrm{l}^{-1} \mathrm{PO}_{4}{ }^{3-}$ recorded here is still well below recommendations for industrial tomato production of around $160 \mathrm{mg} \mathrm{l}^{-1} \mathrm{PO}_{4}{ }^{3-}$ (Hochmuth \& Hochmuth 

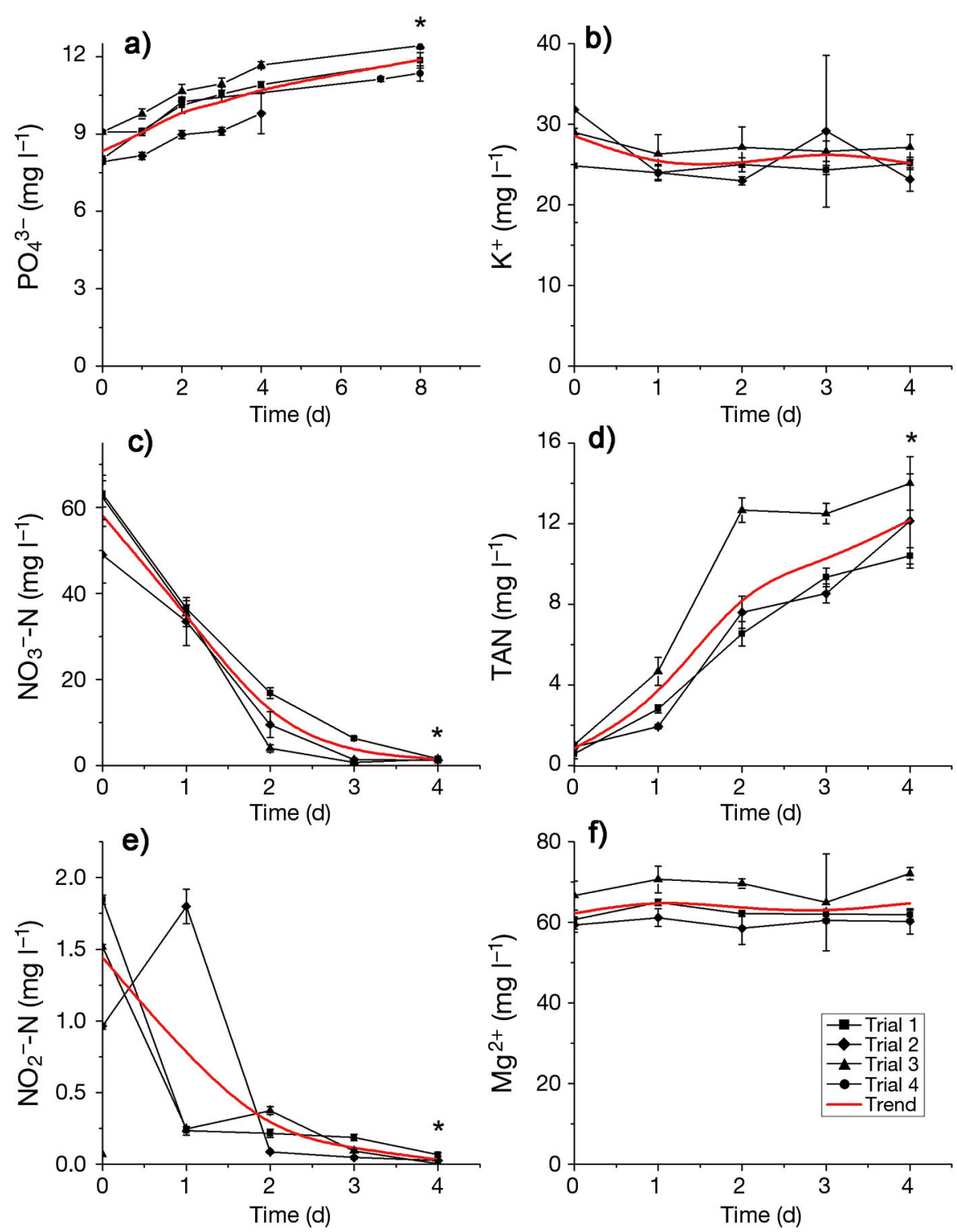

Fig. 2. Soluble nutrients $\left(\mathrm{PO}_{4}{ }^{3-}, \mathrm{K}^{+}\right.$, total ammonia nitrogen [TAN], $\left.\mathrm{NO}_{3}{ }^{-}-\mathrm{N}, \mathrm{NO}_{2}{ }^{-}-\mathrm{N}_{1} \mathrm{Mg}^{2+}\right)$ in the liquid phase of a watersludge mixture derived from a tilapia recirculating aquaculture system over $4 \mathrm{~d}(8 \mathrm{~d}$ only for soluble reactive phosphorus, $\mathrm{PO}_{4}{ }^{3-}$ ) of anaerobic mobilization (Expt 1). Data from 3 successive trials (4 trials for soluble reactive phosphorus $\mathrm{PO}_{4}{ }^{3-}$ ) are presented as mean \pm SD. Trend lines: means of the successive trials (technical replicates). ${ }^{*}$ Significant differences compared to Day 0 are indicated by an asterisk ( $\mathrm{p}<0.05$, Dunn's test, $\mathrm{n}=3$ or 4 trials).

2001). Our results are nonetheless very promising: a prolongation of incubation time as well as technological optimization would probably improve P mobilization further.

$\mathrm{P}$ is a key element for plant nutrition, essential for molecules such as ATP, nucleic acids and phospholipids (Schachtman et al. 1998). An optimal supply is thus essential to maximize plant growth. Recently, $\mathrm{P}$ use as fertilizer for agricultural production is subject of intense discussion in the scientific literature since estimations predict a depletion of this nonrenewable resource (phosphate rock reserves, for human fertilizer utilization) in coming decades (Cooper et al. 2011, McGill 2012); price surges have already been observed (McGill 2012). Currently, P for agricultural crop fertilization is mainly produced by mining (Schmid Neset et al. 2008) and sustainable recycling on a larger scale needs to be explored. Altogether, the increase of phosphate observed in this study particularly highlights the potential for an optimized nutrient recycling in aquaponic systems.

In contrast to $\mathrm{AT}$, anaerobic treatment revealed only minor increases in SRP in the lab-scale experiments and even a slight decrease in the upscaling ex- 

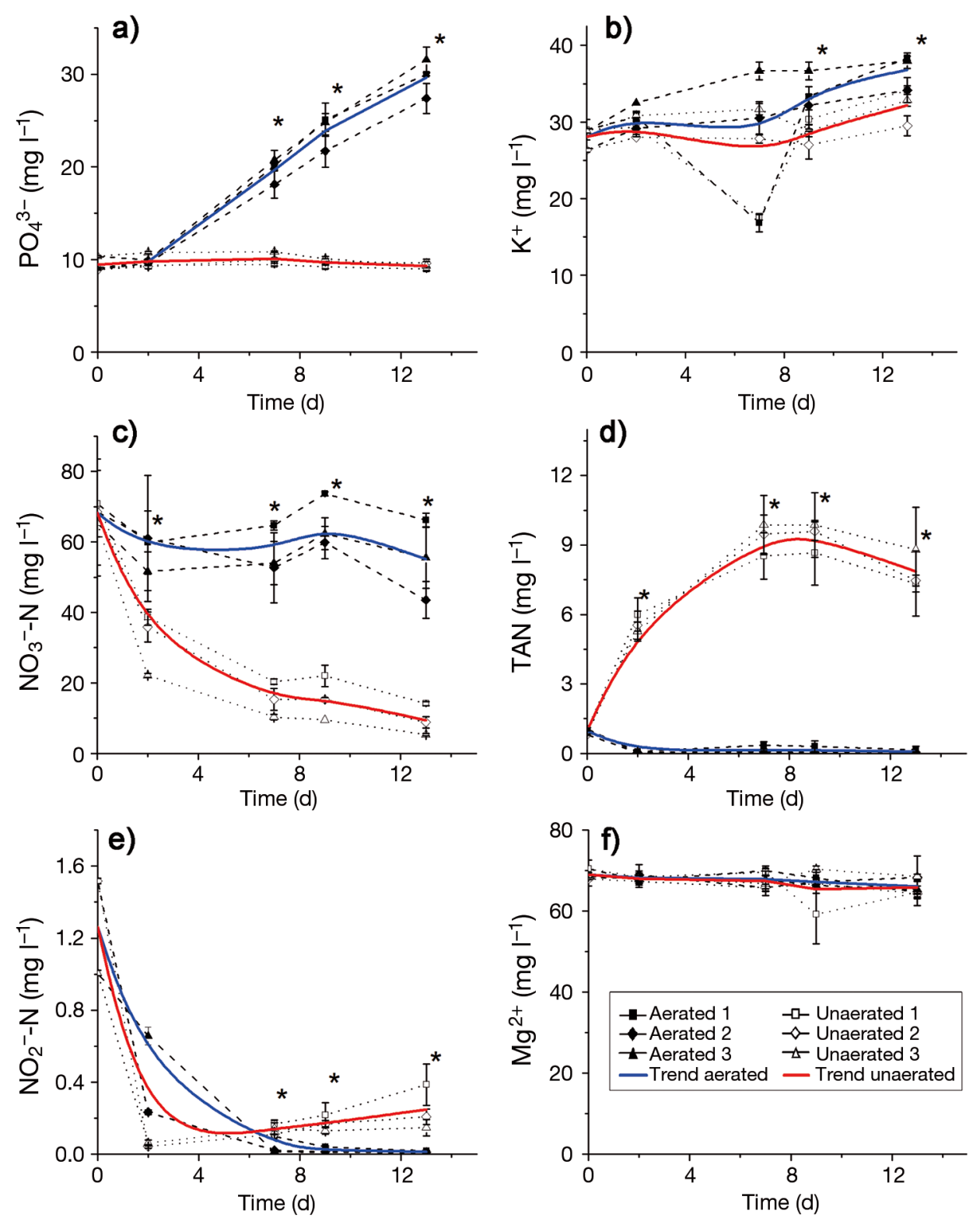

Fig. 3. Soluble nutrients (as in Fig. 2) in the liquid phase of a water-sludge mixture derived from a tilapia recirculating aquaculture system over $14 \mathrm{~d}$ (Day 0 to Day 13) of anaerobic $\left(<0.1 \mathrm{mg} \mathrm{O}_{2} \mathrm{l}^{-1}\right.$, red) and aerobic (blue) treatment (Expt 2). Data from 3 successive trials per treatment are presented as means $\pm \mathrm{SD}$. Trend lines: mean of the successive trials. ${ }^{*}$ Significant differences between anaerobic and aerobic mobilization ( $\mathrm{p}<0.05$, Mann-Whitney $U, \mathrm{n}=3$ trials per treatment)

periments. Similarly, Jung \& Lovitt (2011) reported a P-release of less than $5 \%$ within $7 \mathrm{~d}$ in anaerobic treatment of sludge from a trout farm. However, additional supplementation with glucose led to a final P-release of $90 \%$. Interestingly, as suggested by those authors, glucose addition might not exhibit a direct effect on the P-release (e.g. by increase of P-solubilizing heterotrophs). Instead, lowering of the $\mathrm{pH}$ by glucose fermentation seemed to increase P leaching substantially (Jung \& Lovitt 2011). In contrast to our study, a pH drop below 5 was observed after $24 \mathrm{~h}$.
Furthermore, leaching of different nutrients including $P$ was increased upon the addition of acids. Similarly, $\mathrm{pH}$-dependent mobilization of $\mathrm{P}$ from fish sludge was also reported by Conroy \& Couturier (2010). In our experiments, decreasing $\mathrm{NO}_{3}{ }^{-}-\mathrm{N}$ indicated denitrification in all anaerobic treatments. Thus, proton consumption during denitrification (Klas et al. 2006) seemed to stabilize the $\mathrm{pH}$ in the anaerobic treatments, thereby reducing $\mathrm{P}$ (SRP) mobilization.

Accordingly, in the AT, continuous reduction in $\mathrm{pH}$ to 5.26 ( \pm 0.01$)$ over $14 \mathrm{~d}$ could mainly explain $\mathrm{P}$ 


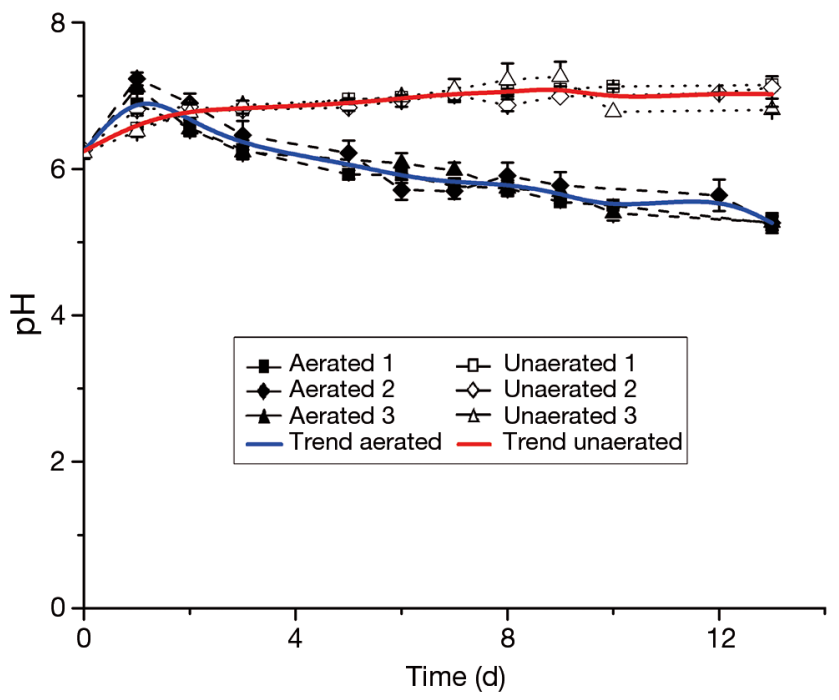

Fig. 4. $\mathrm{pH}$ in the liquid phase of a water-sludge mixture derived from a tilapia recirculating aquaculture system over $14 \mathrm{~d}$ (Day 0 to Day 13) of anaerobic $\left(<0.1 \mathrm{mg} \mathrm{O}_{2} \mathrm{l}^{-1}\right.$, red) and aerobic (blue) mobilization. Data from 3 successive trials are presented as means \pm SD. Trend line: mean of the successive trials (technical replicates)

leaching in the present study. Here, both, nitrification processes as well as respiratory $\mathrm{CO}_{2}$ production contribute to acidification in the incubator (Paredes et al. 2007, Wurts \& Durborow 1992). An extended retention time and/or refilling with new sludgewater mixture or concentrated sludge could consequently speed up the $\mathrm{pH}$ decrease required and hence improve the mobilization.

During the study, we determined the $\mathrm{P}$ binding fractions in the sludge according to a modified sequential P fractionation scheme according to Hupfer et al. (1995) used in aquatic and soil science (Psenner et al. 1984). P fractionation results showed that $50 \%$ of TP were Ca-associated and thus $\mathrm{pH}$ sensitive. In the sequential $\mathrm{P}$ fractionation scheme this fraction is extracted with $\mathrm{HCl}$ and is determined as acid-soluble $\mathrm{P}$ fraction. Accordingly, when the $\mathrm{pH}$ decreases, a major part of the $\mathrm{P}$ in the fish sludge can be mobilized and become available for the crop plants. The second largest P-fraction $(26 \%)$ in the sludge was loosely bound $\mathrm{P}$ (extracted with $\mathrm{NH}_{4} \mathrm{Cl}$ ) and is thus also easily mobilized. Finally, $\sim 5 \%$ of the extracted $\mathrm{P}$ were associated with organic substances (poly-phosphates and humic substances; extracted with $\mathrm{NaOH}$ ). Here, mobilization requires complex microbial digestion. An effective microflora established in the incubator may improve mobilization in the future, compared to the static approach assessed here. In our experiment, SRP increased by $20.2 \mathrm{mg} \mathrm{l}^{-1}$ and is estimated to represent a total of $30 \mathrm{~g} P$ mobilized from the sludge har- vested from the clarifier $\left(1.5 \mathrm{~m}^{3}\right)$ after $1 \mathrm{wk}$. The solid phase analyses of the fish sludge from the clarifier revealed TP values of $60 \mathrm{~g}_{\text {harvest }}{ }^{-1}$. Thus, considering the fractionation analysis, this increase may only result from $\mathrm{pH}$-labile $\mathrm{P}(50 \%$ of TP) in the fish sludge.

Compared to AT, anaerobic treatment is less efficient in the incubator used, but could be optimized by addition of acids, carbon sources and/or bacterial suspension. Undoubtedly, even after completion of the necessary research, an optimised anaerobic treatment process would still require further maintenance effort, resources and the reoxygenation of anaerobic water for subsequent hydroponic application. More important, nitrate, which constitutes the most important nutrient source derived from RAS, would be lost for aquaponic application. Here, an easy-to-handle approach was evaluated particularly with regard to the requirements in aquaculture practice and the need for cost-optimization in current aquaculture operations.

Undoubtedly, the choice of fish species and feed used is utmost relevant in this respect. Particularly for tilapia Oreochromis niloticus, due to economic feasibility, fishmeal is often fully substituted by plant ingredients (e.g. soybean meal, rape seed press cake and meal) without adverse effects on fish performance (El-Saidy \& Gaber 2002). With regard to the current trend towards sustainable aquafeeds replacing fishmeal (Samuel-Fitwi et al. 2012, Slawski et al. 2012, Tusche et al. 2012, 2013) phytate is the main storage form for $\mathrm{P}$ in plant ingredients. Here, phosphate bioavailability is reduced, requiring enzymatic (phytase) conversion (Kumar et al. 2012). Thus, the use of animal protein derived from sustainable resources such as blood, insect or feather meal is a worthwhile strategy to optimize diets for aquaponics in the future. Alternatively, one could increase mobilization of plant-derived, organic P by optimizing enzymatic conversion either by using phytase supplementation in the fish diet (which would also increase $\mathrm{P}$ availability for the fish and thus improve fish nutrition) or by increasing microbial conversion. The latter will inevitably require a more sophisticated incubator that may not be feasible under the current economic and operational conditions.

The increase of $\mathrm{K}^{+}$by $31 \%$ is particularly relevant in tomato production since this macronutrient is required in large amounts and is currently only covered by artificial fertilization (Lattauschke 2004). Nevertheless, $\mathrm{K}^{+}$is not a scarce resource like $\mathrm{P}$ and the increase was not as significant as the increase in P. Still, optimized nutrient management in aquaponics should ultimately aim to minimize use of artificial 
fertilizer. Also, to our knowledge, current legislation and fees for aquaculture emissions do not consider respective $\mathrm{K}^{+}$concentrations. Nevertheless, envisioning sustainable nutrient re-use, future studies should focus on an overall optimization strategy to ensure an environmentally friendly production cycle.

In this context, although not determined in our study, potential accumulation of sodium has to be considered since this is an important issue in hydroponics. Up to a point, excess $\mathrm{NaCl}$ in the nutrient solution can be excluded by the plants; however, in a recirculating system this will result in a steady increase in salt concentration (Blom-Zandstra et al. 1998). Therefore hydroponics nutrient solution is frequently renewed to avoid excessively high salt concentrations and thus to prevent reduction of fruit yield or increased sensitivity to diseases (Post \& Klein-Buitendijk 1996a,b).

The reduction of $\mathrm{NO}_{3}{ }^{-}-\mathrm{N}$ by $19 \%$ is only relevant in critical periods, when imbalances between standing stock of fish and plant production cannot be avoided, for example upon harvest or in periods when fish growth varies unexpectedly (e.g. stress). In wellbalanced aquaponic systems, the reduction could be of minor relevance since intensive RAS production supports high $\mathrm{NO}_{3}{ }^{-} \mathrm{N}$ concentrations of up to $1000 \mathrm{mg} \mathrm{l}^{-1}$ in the rearing water, and blending with water from the sludge incubator can easily be compensated (van Rijn 2013). Under anaerobic conditions, loss of nitrogen due to denitrification was substantial and has to be taken into account for the overall evaluation of AT and UT studied here.

In the present study, TS was lower than in other studies. For example, Conroy \& Couturier (2010) reported $109 \mathrm{~g} \mathrm{l}^{-1}$ TS before initiating anaerobic treatment, i.e. 50 to 100 times higher than in the present study. This mostly results from differently concentrated sludge. Here, we prioritized a simple, easy-to-handle harvest of sludge. Still, both studies identified a $\mathrm{P}$ mobilization after a drastic drop in $\mathrm{pH}$ below 6. Consequently, it can be concluded that mobilization is-mainly-observed after acidification. Furthermore, higher TS may result in acidification due to massive fermentation under anaerobic conditions, whereas at lower TS acidification due to respiration at $\mathrm{AT}$ is demonstrated here. Together, this emphasizes the principal role of $\mathrm{pH}$ in sludge treatment. With respect to handling, system safety and reducing labour costs and providing a robust sludge treatment, aerobic treatment of water-sludge mixture can easily be integrated in aquaponic systems and, compared to anaerobic treatment, does not imply a loss of nitrogen by anaerobic denitrification.

\section{CONCLUSIONS}

In our study we comparatively evaluated a simple, easy-to-handle sludge incubation under aerobic and anaerobic treatment to improve the mobilization of important nutrients required for plant production. Here, aeration establishes aerobic conditions, and lowers the $\mathrm{pH}$ (via respiration and nitrification), subsequently supporting mobilization of $\mathrm{P}$ and $\mathrm{K}^{+}$with minor losses of $\mathrm{NO}_{3}{ }^{-}-\mathrm{N}$. Thereby, the delivery of these nutrients for the crop plant production is clearly improved in the overall system, reducing nutrient emission from sludge disposal. In contrast, anaerobic conditions (e.g. as in denitrification units) revealed a complete loss of $\mathrm{NO}_{3}{ }^{-}-\mathrm{N}$, poses the risk of undesired byproducts and, in practice, is more complicated to handle under commercial conditions. Based on our results we recommend a simple aeration (aerobic treatment) for the effective nutrient mobilization for aquaponics. Still it needs to be emphasized that economic feasibility and biological safety has to be proven. Also, application might be restricted to highly technical and complex systems.

Acknowledgements. We thank Jonas Wagner for his help during the study. H.M. was funded with a scholarship by the Elsa-Neumann-Stiftung (Berlin, Germany). We are equally grateful for the support of the EU Aquaponics Hub (FA1305) COST action network. The publication of this article was partly funded by the Open Access Fund of the Leibniz Association.

\section{LITERATURE CITED}

Barak Y, Van Rijn J (2000) Biological phosphate removal in a prototype recirculating aquaculture treatment system. Aquacult Eng 22:121-136

Blom-Zandstra M, Vogelzang SA, Veen BW (1998) Sodium fluxes in sweet pepper exposed to varying sodium concentrations. J Exp Bot 49:1863-1868

Conroy J, Couturier M (2010) Dissolution of minerals during hydrolysis of fish waste solids. Aquaculture 298:220-225

Cooper J, Lombardi R, Boardman D, Carliell-Marquet C (2011) The future distribution and production of global phosphate rock reserves. Resour Conserv Recycling 57: 78-86

* Dawson CJ, Hilton J (2011) Fertiliser availability in a resource-limited world: production and recycling of nitrogen and phosphorus. Food Pol 36 (Suppl 1):S14-S22

Edwards P (2015) Aquaculture environment interactions: past, present and likely future trends. Aquaculture 447: $2-14$

El-Saidy DMSD, Gaber MMA (2002) Complete replacement of fish meal by soybean meal with dietary L-lysine supplementation for Nile tilapia Oreochromis niloticus (L.) fingerlings. J World Aquacult Soc 33:297-306

Goddek S, Delaide B, Mankasingh U, Ragnarsdottir K, Jijakli H, Thorarinsdottir R (2015) Challenges of sustainable and commercial aquaponics. Sustainability 7:4199-4224 
Gutierrez-Wing MT, Malone RF (2006) Biological filters in aquaculture: trends and research directions for freshwater and marine applications. Aquacult Eng 34:163-171

Hochmuth GJ, Hochmuth RC (2001) Nutrient solution formulation for hydroponic (perlite, rockwool, NFT) tomatoes in Florida. HS796. University of Florida Cooperative Extension Service, Gainesville, FL

Hua K, Bureau DP (2006) Modelling digestible phosphorus content of salmonid fish feeds. Aquaculture 254:455-465

Hupfer M, Gächter R, Giovanoli R (1995) Transformation of phosphorus species in settling seston and during early sediment diagenesis. Aquat Sci 57:305-324

Jung IS, Lovitt RW (2011) Leaching techniques to remove metals and potentially hazardous nutrients from trout farm sludge. Water Res 45:5977-5986

Klas S, Mozes N, Lahav O (2006) A conceptual, stoichiometry-based model for single-sludge denitrification in recirculating aquaculture systems. Aquaculture 259:328-341

Kumar V, Sinha AK, Makkar HPS, De Boeck G, Becker K (2012) Phytate and phytase in fish nutrition. J Anim Physiol Anim Nutr 96:335-364

Lattauschke G (2004) Gewächshaustomaten: Hinweise zum umweltgerechten Anbau-Managementunterlage. Book 1. Fachbereich Gartenbau, Sächsische Landesanstalt für Landwirtschaft, Pillnitz

McGill SM (2012) 'Peak' phosphorus? The implications of phosphate scarcity for sustainable investors. J Sustain Finance Invest 2:222-239

Mirzoyan N, Tal Y, Gross A (2010) Anaerobic digestion of sludge from intensive recirculating aquaculture systems. Rev Aquacult 306:1-6

Murphy J, Riley JP (1962) A modified single solution method for the determination of phosphate in natural waters. Anal Chim Acta 27:31-36

Neori A, Krom MD, van Rijn J (2007) Biogeochemical processes in intensive zero-effluent marine fish culture with recirculating aerobic and anaerobic biofilters. J Exp Mar Biol Ecol 349:235-247

O'Sullivan P, Reynolds CS (2004) The lakes handbook: limnology and limnetic ecology. Wiley-Blackwell, Oxford

*Paredes D, Kuschk P, Mbwette TSA, Stange F, Müller RA, Köser H (2007) New aspects of microbial nitrogen transformations in the context of wastewater treatmenta review. Eng Life Sci 7:13-25

Post WHK, Klein-Buitendijk H (1996a) Zoutonderzoek bij paprika. Invloed van natrium, calcium en kalium/magnesium verhoudingen op produktie en kwaliteit. Intern Verslag 29, Proefstation voor Bloemisterij en Glasgroente, Naaldwijk

Post WHK, Klein-Buitendijk H (1996b) Zoutonderzoek bij

Editorial responsibility: Symon Dworjanyn, Coffs Harbourg, New South Wales, Australia paprika. Invloed van natrium en kalium op produktie en kwaliteit. Intern Verslag 28, Proefstation voor Bloemisterij en Glasgroente, Naaldwijk

Psenner R, Pucsko R, Sager M (1984) Die Fraktionierung organischer und anorganischer Phosphorverbindungen von Sedimenten - Versuch einer Definition ökologisch wichtiger Fraktionen. Arch Hydrobiol (Suppl) 70: 111-155

Rakocy JE, Masser MP, Losordo TM (2006) Recirculating aquaculture tank production systems: aquaponics - integrating fish and plant culture. South Region Aquacult Cent (SRAC) Publ 454:1-16

Rakocy JE, Bailey DS, Shultz RC, Danaher JJ (2007) Preliminary evaluation of organic waste from two aquaculture systems as a source of inorganic nutrients for hydroponics. Acta Hortic 201-207

Rennert B, Groß R, van Ballegooy C, Kloas W, (2011) Ein Aquaponiksystem zur kombinierten Tilapia- und Tomatenproduktion. Fisch Teichwirt 2011(6):209-214

Samuel-Fitwi B, Wuertz S, Schroeder JP, Schulz C (2012) Sustainability assessment tools to support aquaculture development. J Clean Prod 32:183-192

Schachtman DP, Reid RJ, Ayling SM (1998) Phosphorus uptake by plants: from soil to cell. Plant Physiol 116: 447-453

Schmid Neset TS, Bader HP, Scheidegger R, Lohm U (2008) The flow of phosphorus in food production and consumption - Linkoping, Sweden, 1870-2000. Sci Total Environ 396:111-120

Slawski H, Adem H, Tressel RP, Wysujack K and others (2012) Total fish meal replacement with rapeseed protein concentrate in diets fed to rainbow trout (Oncorhynchus mykiss Walbaum). Aquacult Int 20:443-453

Tusche K, Arning S, Wuertz S, Susenbeth A, Schulz C (2012) Wheat gluten and potato protein concentrate-promising protein sources for organic farming of rainbow trout (Oncorhynchus mykiss). Aquaculture 344-349:120-125

Tusche K, Nagel F, Arning S, Wuertz S, Susenbeth A, Schulz C (2013) Effect of different dietary levels of potato protein concentrate supplemented with feed attractants on growth performance of rainbow trout (Oncorhynchus mykiss). Anim Feed Sci Technol 183:202-209

Van Rijn J (2013) Waste treatment in recirculating aquaculture systems. Aquacult Eng 53:49-56

Wurts WA, Durborow RM, (1992) Interactions of $\mathrm{pH}$, carbon dioxide, alkalinity and hardness in fish ponds. South Region Aquacult Cent (SRAC) Publ 464:1-4

Z Zhang Y, Bleeker A, Liu JG (2015) Nutrient discharge from China's aquaculture industry and associated environmental impacts. Environ Res Lett 10:045002

Submitted: April 29, 2016; Accepted: October 25, 2016

Proofs received from author(s): January 10, 2017 